\title{
Tobacco education in medical schools: survey among primary care physicians in Bahrain I. Fadhil ${ }^{1}$
}

$$
\text { التثقيف حول التبخ في كليات الطب: مسح بين أطباء الرعاية الأولية في البحرين }
$$

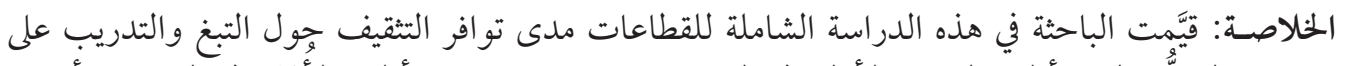

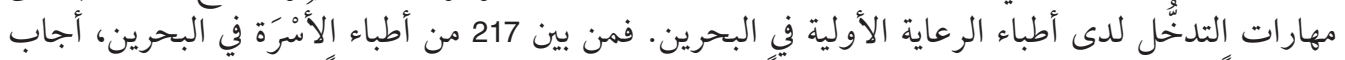

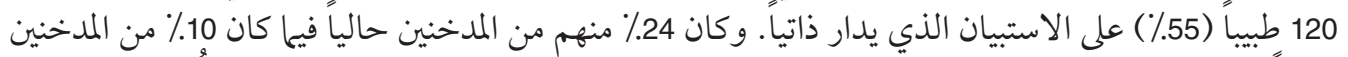

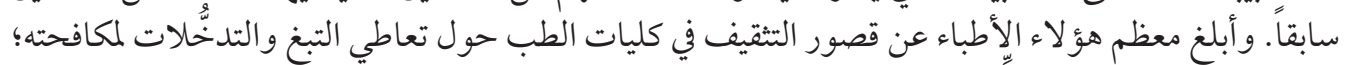

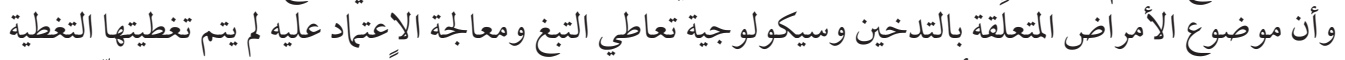

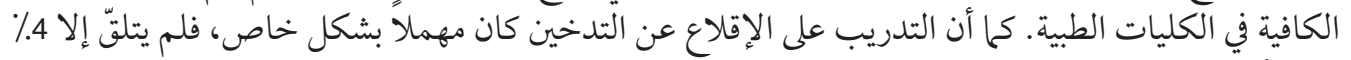

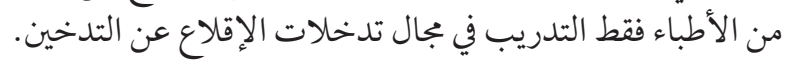

ABSTRACT This cross-sectional study assessed the extent of tobacco education and intervention skills training among primary care physicians in Bahrain. Out of 217 family physicians in the country, $120(55 \%)$ answered a self-administered questionnaire. A total of $24 \%$ were current smokers and $10 \%$ were ex-smokers. Inadequate education at medical school about tobacco use and interventions was reported by the majority of physicians. The subject of smoking-related diseases, psychology of tobacco use and management of tobacco dependence were inadequately covered in medical schools. Training in smoking cessation was particularly neglected, with only $4 \%$ of physicians receiving training about tobacco cessation interventions.

\begin{abstract}
Information sur le tabac dans les écoles de médecine : enquête auprès des médecins de soins primaires à Bahreïn

RÉSUMÉ Cette étude transversale a évalué l'importance de l'information sur le tabac et de l'acquisition de compétences en matière d'interventions chez les médecins de soins primaires de Bahreïn. Sur 217 médecins de famille dans le pays, 120 (55\%) ont répondu à un questionnaire auto-administré. Au total, $24 \%$ étaient fumeurs au moment de l'étude et $10 \%$ étaient d'anciens fumeurs. La plupart de ces médecins ont déclaré que l'enseignement dispensé dans les écoles de médecine à propos de la consommation de tabac et des interventions associées était inadapté. Les maladies liées au tabagisme, la psychologie du fumeur et la prise en charge de la dépendance tabagique n'étaient pas suffisamment abordées dans ces écoles. La formation en matière de sevrage tabagique était particulièrement négligée, seuls $4 \%$ des médecins ayant appris à effectuer des interventions dans ce domaine.
\end{abstract}

${ }^{1}$ Chronic Diseases Unit, Ministry of Health, Manama, Bahrain (Correspondence to I. Fadhil: ifadhil@hotmail. com).

Received: 09/07/06; accepted: 11/01/07

المجلة الصحية لشرق المتو سط، منظمة الصحة العالمية، المجلد الخامس عشر، العدد ع، 9 +. 


\section{Introduction}

Tobacco use kills millions of people each year. World Health Organization (WHO) epidemiologists predict that unless there is a dramatic change in present trends, tobacco will be killing 8.4 million people a year by the late 2020s [1].

Physicians have an important role to play in tobacco control activities as they have both access to and influence over the population of smokers. They can initiate and monitor cessation treatment with smokers [2]. Most studies have shown that even very brief advice from doctors yields 1 -year quit rates of $5 \%-10 \%[3,4]$ and that interventions that include follow-up sessions produce abstinence rates of $20 \%-36 \%$ [4-6]. Recording tobacco history use for each patient, particularly patients with chronic diseases, is important.

However, a recent British study reported that less than one-third of smokers could recall being given advice to quit by their general practitioner [7]. In Australia just over $50 \%$ of smokers had been given such advice, and general practitioners could identify only $62 \%$ of their patients who smoked $[8,9]$. WHO has focused on the role of health professionals in the tobacco control process. The theme for World No Tobacco day in 2005 was the role of health professionals in tobacco control.

In Bahrain, the prevalence of smoking was reported to be $29.5 \%$ among males aged 19 years and over and $18.6 \%$ among females of the same age group [10]. A study of smoking prevalence among population subgroups showed that $22.1 \%$ of primary care physicians and $1.9 \%$ of female physicians in Bahrain were smoking on a regular basis, while $34.6 \%$ of male dentists and $11.5 \%$ of female dentists were smokers [11]. There is also evidence of a rising prevalence of smoking among youth in Bahrain. The Global Youth Tobacco Survey reported a smoking rate of $33.5 \%$ among males and $11.9 \%$ among females aged $13-15$ years [12].

Part of the Bahraini Ministry of Health $(\mathrm{MOH})$ response to the public health problem of tobacco focuses on the role of health professionals in tobacco control. Therefore it is important at this stage to identify physicians' need for training and education in the area of tobacco prevention and management of nicotine addiction in patients. The main objectives of the present study were to look at the extent of tobacco education and training received in medical schools by primary care physicians in Bahrain and to establish whether the physicians felt well-equipped to deliver smoking cessation interventions in their clinical practice.

\section{Methods}

There are 22 primary health centres in Bahrain with a total of 217 primary care physicians. The data for the survey were collected during a workshop for primary care physicians organized by the Ministry of Health in early 2005. The workshop aimed at capacity-building and maximizing the involvement of primary health professionals in tobacco control activities. The participants were all primary care physicians representing the professionals at each health centre. All physicians at the workshop ( $n$ $=120$ ) participated in the study.

The survey used a self-completion questionnaire with the following items:

- Demographic data (age, sex, nationality, medical school attended and smoking status).

- Tobacco training and education received in medical school, including: knowledge of the adverse health effects of tobacco use and passive smoking; knowledge about the nature of tobacco use; aware- 
ness of nicotine replacement products; smoking cessation training; and knowledge about the available pharmacotherapy, behavioural therapy and other evidence-based interventions.

- Beliefs and perceptions about the physician's role in tobacco control.

All questions were completed anonymously. The completed questionnaires were collected by the author.

Descriptive statistics and data management were generated using Epi-Info, version 6. Forms with missing responses to a few questions numbered less than 3 , and these were included in the study.

\section{Results}

The majority of participating physicians $(88 \%)$ were Bahraini nationals. There were $36 \%$ male and $64 \%$ female physicians. The mean age was 36.5 years. Only $23 \%$ had completed their medical training in Bahrain (at the Arabian Gulf University); the majority $(77 \%)$ had been trained outside Bahrain at various medical universities (in Egypt, Saudi Arabia, India and others) (Table 1).

Nearly one-quarter (24\%) of the physicians reported being smokers, $10 \%$ were ex-smokers and $66 \%$ were never smokers (Table 1). Of the current smokers, $3 \%$ regularly smoked tobacco in waterpipes (shisha).

\section{Tobacco education at medical school}

The responses to questions about tobacco education and knowledge of harmful effects of tobacco use received during medical school training are shown on Table 2.

The majority of the physicians $(87 \%)$ reported that their course had covered in detail the effects of tobacco use on both

\begin{tabular}{|c|c|c|}
\hline Characteristic & No. & $\%$ \\
\hline \multicolumn{3}{|l|}{ Sex } \\
\hline Male & 43 & 36 \\
\hline Female & 77 & 64 \\
\hline \multicolumn{3}{|c|}{ Medical school attended } \\
\hline Bahraini & 28 & 23 \\
\hline Overseas & 92 & 77 \\
\hline \multicolumn{3}{|l|}{ Nationality } \\
\hline Bahraini & 106 & 88 \\
\hline Non-Bahraini & 14 & 12 \\
\hline \multicolumn{3}{|l|}{ Age (years) } \\
\hline$<30$ & 13 & 11 \\
\hline 30-39 & 48 & 40 \\
\hline $40-49$ & 42 & 35 \\
\hline $50-59$ & 14 & 12 \\
\hline $60+$ & 3 & 3 \\
\hline \multicolumn{3}{|l|}{ Smoking status } \\
\hline Smoker & 29 & 24 \\
\hline Cigarettes only & 22 & 18 \\
\hline Waterpipe & 3 & 3 \\
\hline Both & 4 & 3 \\
\hline Non-smoker & 91 & 76 \\
\hline Ex-smoker & 12 & 10 \\
\hline Never smoker & 79 & 66 \\
\hline
\end{tabular}

the respiratory and cardiovascular systems. However, only $38 \%$ said that it had covered the effect of tobacco use on the genitourinary system, including cancer of the bladder, $14 \%$ the reproduction system, and $12 \%$ the effect on skin and connective tissues (Table 2).

Only $13 \%$ of the physicians reported that they had covered the subject of tobacco dependence at medical school; even fewer physicians had been taught about the psychology of smoking (e.g. reasons why people tend to smoke) and about the difficulty people have in stopping smoking $(8 \%$ and $4 \%$ respectively) (Table 2 ).

The physicians were asked about their perceptions regarding tobacco use; $12 \%$ of

المجلة الصحية لشرق المتوسط، منظمة الصحة العالمية، المجلد الخنامس عشر، العدد ع، 9 +. 
Table 2 Distribution of physicians regarding education on tobacco control issues and smoking cessation interventions at medical school $(n=120)$

\begin{tabular}{|c|c|c|}
\hline Item & No. & $\%$ \\
\hline \multicolumn{3}{|l|}{$\begin{array}{l}\text { Received training on smoking- } \\
\text { related diseases of: }\end{array}$} \\
\hline Respiratory system & 104 & 87 \\
\hline Digestive system & 98 & 82 \\
\hline Cardiovascular system & 110 & 92 \\
\hline Nervous system & 38 & 32 \\
\hline $\begin{array}{l}\text { Genitourinary \& reproductive } \\
\text { system }\end{array}$ & 63 & 52 \\
\hline Skin and connective tissues & 14 & 12 \\
\hline \multicolumn{3}{|l|}{$\begin{array}{l}\text { Received training on } \\
\text { psychology of smoking }\end{array}$} \\
\hline Yes & 10 & 8 \\
\hline No & 110 & 92 \\
\hline \multicolumn{3}{|l|}{$\begin{array}{l}\text { Received training on difficulty } \\
\text { in stopping smoking }\end{array}$} \\
\hline Yes & 5 & 4 \\
\hline No & 115 & 96 \\
\hline \multicolumn{3}{|l|}{$\begin{array}{l}\text { Received training on smoking } \\
\text { cessation interventions }\end{array}$} \\
\hline Yes & 18 & 15 \\
\hline No & 102 & 85 \\
\hline \multicolumn{3}{|l|}{$\begin{array}{l}\text { Familiar with behavioural } \\
\text { therapy for smoking cessation }\end{array}$} \\
\hline Yes & 12 & 10 \\
\hline No & 108 & 90 \\
\hline \multicolumn{3}{|l|}{$\begin{array}{l}\text { Familiar with NRT for smoking } \\
\text { cessation }\end{array}$} \\
\hline Yes & 108 & 91 \\
\hline No & 12 & 9 \\
\hline \multicolumn{3}{|l|}{$\begin{array}{l}\text { Familiar with non-nicotine } \\
\text { medications (bupropion) for } \\
\text { smoking cessation }\end{array}$} \\
\hline Yes & 16 & 13 \\
\hline No & 104 & 87 \\
\hline
\end{tabular}

the physicians perceived tobacco use as an addiction with its corresponding withdrawal symptoms, while $10 \%$ saw it as a habit; $78 \%$ believed that tobacco use is both a
Table 3 Physicians' beliefs, attitudes and practices toward tobacco use and on responsibility for management of tobacco dependence $(n=120)$

\begin{tabular}{lcc}
\hline Item & No. & $\%$ \\
\hline Believe that smoking is: & & \\
$\quad$ An addiction & 14 & 12 \\
A habit & 12 & 10 \\
$\quad$ Both & 94 & 78 \\
$\begin{array}{l}\text { Believe that is it important to } \\
\text { record personal tobacco use }\end{array}$ & & \\
$\quad$ Yes & 62 & 52 \\
No & 58 & 48
\end{tabular}

Practise recording full history of patients' tobacco use

$\begin{array}{lrr}\text { Yes } & 5 & 4 \\ \text { No } & 115 & 96\end{array}$

Believe the health professional responsible for management of tobacco dependence is:

$\begin{array}{lll}\text { Physician } & 46 & 38 \\ \text { Nurse } & 24 & 20 \\ \text { Psychologist } & 94 & 78 \\ \text { Pharmacist } & 58 & 48 \\ \text { Social worker } & 26 & 22\end{array}$

Believe that smoking cessation therapy should be subsidized $\quad 116 \quad 97$

form of addiction and also a behavioural habit (Table 3).

\section{Recording patients' tobacco use}

The majority of physicians $(88 \%)$ reported having brief training about the need to record the tobacco history of patients. However, while $52 \%$ of physicians believed that eliciting tobacco history was important, a mismatch existed between perceived importance and their current practice. Almost none of the physicians (4\%) actually recorded patients' tobacco use (Table 3). Lack of time, heavy workload and lack of motivation were the main obstacles stated by the majority of respondents. 
Training on smoking cessation interventions

Almost all the physicians (85\%) said they had received no formal training on smoking cessation interventions at medical school (Table 2). No differences were noted between physicians trained locally and overseas with regard to smoking cessation training.

While $91 \%$ of physicians were familiar with nicotine replacement therapy (e.g. chewing gum and skin patches), they stated that their knowledge was gained in practice and not at medical school training. Only $13 \%$ of physicians knew about bupropion tablets as non-nicotine medication and its role in the management of tobacco dependence and $10 \%$ had heard about the role of other non-pharmacological therapy (e.g. motivational and behavioural therapy, acupuncture, etc.) (Table 2).

The physicians' opinion about the role of physicians versus other health professionals in the management of smokers is shown in Table 3 . The majority (78\%) believed that psychologists were the health professionals responsible for management of tobacco dependence. Half of the physicians (48\%) thought that pharmacists were responsible and only $36 \%$ believed in the role of physicians in the management of tobacco use. Almost all physicians (97\%) considered funding for the smoking cessation medication as essential for the success for smoking cessation programmes.

More than $90 \%$ of respondents indicated that additional information or training on behavioural techniques for quitting smoking would be "extremely" or "somewhat" helpful.

\section{Discussion}

There is clear evidence that doctors and primary care physicians play an important role in assisting patients with smoking cessation
[13-16]. However, adequate education and training is essential.

The present study revealed that $24 \%$ of primary care physicians were smokers. Similar rates among primary care physicians in Bahrain were reported previously $(26.6 \%$ and $23.8 \%)[17,18]$. While the smoking rate among the general adult male population in Bahrain is higher (29.5\%) [10], the rate of smoking among male physicians is of concern and may undermine their credibility in the management of smokers and minimize their role in tobacco control programmes.

The results of this study reflect deficiencies in physicians' knowledge about tobacco harm. Only $14 \%$ and $12 \%$ of physicians respectively were taught about the harmful effects of tobacco on the reproductive system and connective tissues. The international study conducted by the International Union Against Tuberculosis and Lung Diseases found major deficits in knowledge among medical students with regard to the diseases less commonly associated with tobacco, as well as skills related to tobacco dependence counselling [13].

Education gaps were noted again in areas related to tobacco use and dependence. Only $12 \%$ of physicians were taught about the psychology of nicotine addiction. Similarly there were deficiencies in physician's education about why people smoke and the difficulty in quitting smoking. These deficits may be associated with general shortcomings in tobacco education strategies and the tobacco education curriculum at universities.

Despite the fact that recording patients' tobacco use and history are important, particularly for patients with chronic disease, our study showed that the majority of physicians were not trained to take a tobacco history. While $52 \%$ of physicians believed in the significance of tobacco history, 96\% did not comply with this and explained their

المجلة الصحية لشرق المتوسط، منظمة الصحة العالمية، المجلد الخنامس عشر، العدد ع، 9 +. 
inadequate performance as due to heavy workload at primary care centres and lack of motivation.

For management of tobacco use and dependence, the majority of physicians had no formal training. Furthermore, physician's knowledge about the measures available for smoking cessation was inadequate. While $91 \%$ of the physicians knew about nicotine replacement therapy, only $13 \%$ were aware of non-nicotine medication (bupropion), and only $10 \%$ knew about the role of other measures (e.g. counselling, acupuncture) in tobacco cessation. These findings reflect missed opportunities for physicians to provide effective smoking cessation counselling and tobacco control interventions.

The results of this study are consistent with the findings of other researchers who investigated tobacco education in medical school curricula. A global survey of medical schools showed that only $11 \%$ had a specific module on tobacco education and
$12 \%$ of schools did not cover the topic of tobacco in the medical curriculum; this was as high as one-quarter in medical schools in Africa and Asia [13,19].

Based on the current tobacco control strategy in Bahrain that attempts to lower tobacco use and maximize the tobacco quit rate, there is a need to review and improve tobacco education and tobacco intervention skills in the curriculum of medical students as well as other health professionals. Most respondents thought that additional information or training on behavioural techniques for quitting smoking would be helpful.

To sum up, the prevalence of smoking is high among primary care physicians in Bahrain (24\%). The majority of physicians had not been trained about eliciting tobacco use history, and only 4\% actually took a tobacco use history from patients. Major training deficiencies in medical schools about smoking cessation interventions were noted.

\section{References}

1. Yu JJ, Shopland DR. Cigarette smoking behavior and consumption characteristics for the Asia-Pacific region. World smoking and health, 1989, 14:7-9.

2. Heywood A et al. Screening for cardiovascular disease and risk reduction counseling behaviors of general practitioners. Preventive medicine, 1994, 23:292-301.

3. Russell MAH et al. Effect of general practitioners' advice against smoking. British medical journal, 1979, 2:231-5.

4. Russell MAH et al. Effect of nicotine chewing gum as an adjunct to general practitioners' advice about smoking. British medical journal, 1983, 287:1782-5.

5. Russell MAH et al. Targeting heavy smokers in general practice: randomized controlled trial of transdermal nicotine patches. British medical journal, 1993, 306:1308-12.

6. Ockene JK. Smoking intervention: the expanding role of the physician. American journal of public health, 1987, 77:782-3.

7. Richmond RL, Austin A, Webster IA. Three year evaluation of a programme by general practitioners to help patients stop smoking. British medical journal, 1986, 292:803-6.

8. Richmond RL et al. One year evaluation of general practitioners' use of three smoking cessation programs. Addictive behaviour, 1993, 18:187-99.

9. Silagy $\mathrm{C}$ et al. Lifestyle advice in general practice: rates recalled by patients. British medical journal, 1992, 305:871-4. 
10. Moosa $\mathrm{K}$ et al. National nutrition survey for adults Bahrainis aged 19 years and above. Manama, Bahrain, Ministry of Health, Nutrition Section, 2002.

11. Behbehani NN, Hamadeh RR, Macklai NS. Knowledge of and attitudes towards tobacco control among smoking and nonsmoking physicians in 2 gulf arab states. Saudi medical journal, 2004, 25 (5):58591.

12. Al-Muqla M, ed. Youth tobacco survey report. Manama, Bahrain, Ministry of Health, 2003.

13. Mullins R, Borland R. Doctors' advice to their patients about smoking. Australian family physician, 1993, 22:1146-55.

14. Spangler JG et al. Tobacco intervention training: current efforts and gaps in US medical schools. Journal of the American Medical Association. 2002, 288:1102-9.
15. Coultas DB. The physician's role in smoking cessation. Clinical chest medicine, 1991, 12:755-68

16. Godshall W. The most compelling smoking cessation incentive a doctor can offer. Tobacco control, 1993, 2:237-8.

17. Hamadeh RR. Smoking habits of primary health care physicians in Bahrain. Journal of the Royal Society for the Promotion of Health, 1999, 119(1):36-9.

18. Hamadeh RR et al. Prevalence of smoking in Bahrain. Tobacco control, 1992, 1:102-6.

19. Roche AM, Eccleston $P$, Sanson-Fisher R. Teaching smoking cessation skills to senior medical students: a blockrandomized controlled trial of four different approaches. Preventive medicine, 1996, 25:251-8.

World Mo Tobacco Day 2009. Show the truth: Picture warnings save lives.

Effective health warnings, especially those that include pictures, have been proven to motivate users to quit and to reduce the appeal of tobacco for those who are not yet addicted. Despite this fact, 9 out of 10 people live in countries that do not require warnings with pictures on tobacco packages.

However, more and more countries are fighting back by requiring that tobacco packages graphically show the dangers of tobacco, as called for in the World Health Organization Framework Convention on Tobacco Control. They use the MPOWER technical assistance package developed by WHO to help meet their commitments under this international treaty. 